\title{
MARTÍNEZ-FALERO, Luis (2009). Gramática, retórica y dialéctica en el siglo XVI. La teoría de la inventio en Antonio Llull. Logroño: Instituto de Estudios Riojanos, 374 pp. ISBN: 978-84-96637-71-9.
}

El profesor Martínez-Falero retoma con su última obra el tema recurrente y principal de su labor crítica: la Retórica y, más concretamente, la teoría de la inventio y la obra del humanista mallorquín Antonio Llull. Desde que en 1999 leyera su Tesis doctoral, bajo el título La teoría retórica de la inventio en Antonio Lulio, nunca ha abandonado el estudio de dicho campo de investigación, consolidándose en la actualidad como uno de los máximos especialistas y referente obligatorio para cualquier investigador que pretenda introducirse en dichos estudios. Ha publicado sus trabajos sobre Retórica en prestigiosas publicaciones como Revista de literatura (1998), Rhetorica (2001) y Dicenda (2002), entre otras; igualmente, realizó la edición de los ejercicios de retórica (Progymnasmata rhetorica) de Llull en el CD-Rom coordinado por Miguel Ángel Garrido Gallardo Retóricas españolas del siglo XVI escritas en latín (Madrid, CSIC, 2004). Durante los últimos años compagina sus estudios de Retórica, con investigaciones sobre Literatura comparada e Imaginario literario.

Este breve apunte sobre su trayectoria crítica nos pone sobre aviso de las cualidades que encierra su último manual. En su redacción queda reflejado el gran conocimiento -adquirido durante años- que el autor posee de las diversas materias de las que se ocupa; al igual que el dominio e inteligente manejo de las fuentes clásicas, medievales y renacentistas que realiza; así como el seguimiento de los estudios más recientes de Retórica publicados a nivel internacional. Todo este caudal de información se somete a un análisis detenido, que muestra el máximo rigor filológico, crítico y bibliográfico que impregna las páginas de esta obra y que todos sus lectores podemos reconocer como marca de identidad en el conjunto de sus investigaciones. Del mismo modo, el volumen constituye una puesta al día sobre la obra luliana, tan atrayente para los investigadores en las últimas décadas, tras reconocer la inmensa aportación de la misma en la Retórica y Poética renacentista y su innegable influencia en épocas posteriores.

El presente volumen se divide en tres partes nítidamente diferenciadas, rotuladas bajo los títulos: "Humanismo, Reforma y contrarreforma", "La teoría de la 
inventio en Antonio Llull" y "La teoría de la argumentación en el tratado De oratione (Libros I y II)". La primera parte se configura como una extensa introducción en la que se expone la situación histórica en la que se encontraba la Iglesia tras la reforma introducida por Valla y la confrontación entre las ideas de Erasmo y Lutero; la inestabilidad del sistema educativo del momento, escindido entre la antigua Escolástica y las propuestas reformadoras de Erasmo y, la pugna entre los pensadores platónicos y los aristotélicos, núcleo del movimiento intelectual de la época. Esta exposición nos ayuda a comprender el momento de crisis en el que se encuentran los estudios humanísticos.

A continuación, se estudia la situación de los estudios de Retórica en este momento. Las primeras incursiones en su definición y análisis se remontan a la Edad Media, pero es en el Renacimiento, cuando dicha disciplina concentra el máximo interés de los humanistas. Martínez-Falero sintetiza y subraya la importancia que adquirieron las principales aportaciones de los diferentes tratadistas en lo referente a dicha materia y su relación con la Dialéctica, la Poética y la Gramática. Por ejemplo, Valla y Trebisonda son los primeros en situar la Retórica como "eje del discurso" y, por tanto, destacarla en un lugar preeminente. Posteriormente, Agrícola propone la separación de la inventio (para él dialéctica). Otros humanistas como Vives, Ramus y El Brocense también dejan patente sus juicios al respecto. Como conclusión, la Retórica pasa a ser el saber máximo en el que se sustenta la construcción del discurso y, de forma subordinada, como partis artis se encuentran la Dialéctica y la Poética, sin olvidar los elementos gramaticales. Este primer bloque se cierra con la descripción del importante debate sobre la imitatio en los estudios humanísticos. La pregunta que pretendieron resolver es si Cicerón se posicionaba como el único referente del mundo clásico digno de ser imitado o si, por el contrario, la obra de otros autores también merecía ser tenida en cuenta.

En la segunda parte de su estudio se centra en la figura de Antonio Llull. Introduce este apartado con la redacción de la biografía del teólogo balear para, seguidamente, trazar un recorrido por las diferentes obras del célebre erudito, prestando especial interés al tratado De oratione libri septem (1558), en el que se encierra sus aportaciones más interesantes a los estudios de Retórica. Uno de los asuntos que centran la atención de Martínez-Falero son las principales influencias teóricas sobre las que Llull cimienta sus estudios, entre las que se encuentran: Aristóteles, Erasmo, Linacre, Hermógenes, Dionisio de Halicarnaso, Aristoxeno, Fox Morcillo, Agrícola, Tomás de Aquino, Pedro Hispano, al igual que diversas fuentes latinas y bizantinas. 
Es en el tratado anteriormente citado en el que Llull sintetiza todas sus ideas sobre Retórica. Martínez-Falero las resume en un ilustrativo esquema (p. 70), en el que se puede comprobar como Llull sitúa la Dialéctica en el centro del sistema organizativo del discurso, a la que se subordinan otros seis saberes: Gramática, Retórica, Poética, Hermenéutica, Teología y Didáctica. De esta forma, el pensador mallorquín se acerca a la posición defendida por Agricola, mientras que se aleja de la que mantienen Valla y Trebisonda, para quienes dicho protagonismo tendría que ser ocupado por la Retórica. Martínez-Falero deconstruye el legado teórico luliano para que los lectores podamos comprender en toda su dimensión cuáles fueron los avances conquistados por el tratadista, cuya obra, como señala Martínez-Falero, mantiene un fuerte eclecticismo, lo que a su vez nos permite comprobar la amplitud de miras y la tolerancia ideológica que caracterizaban a Antonio Llull.

Este volumen se cierra con la traducción de los Libros I y II del tratado De oratione. Dicha traducción nos permite descubrir un nuevo texto, hasta ahora desconocido, gracias a que se han tenido en cuenta las modificaciones que Llull realizó a su primera redacción impresa en 1558; enmiendas que se han hallado en dos ejemplares de la Biblioteca Municipal de Besançon y que, permiten comprobar como el tratadista balear volvió en diversas ocasiones a su obra, sobre la que realizó diversas modificaciones. Dicha traducción vuelve a poner de manifiesto el nivel de exigencia que envuelve el trabajo de Martínez-Falero, capturado en el conjunto del libro.

A modo de conclusión, podemos afirmar que este último título del profesor Martínez-Falero debe de ser consultado de forma obligatoria por investigadores y estudiantes de Retórica y Teoría literaria pero, sin lugar a dudas, considero que también debería suscitar el interés de historiadores de la lengua y de la literatura de los Siglos de Oro, e incluso, de historiadores de la filosofía. En un sistema académico que camina obligatoriamente $\mathrm{y}$, sin un posible retroceso, hacia la interdisciplinariedad, resulta indiscutible que el manual que ahora se presenta, a pesar de no presentar una lectura amena -no es posible dentro del campo de estudio en el que se sitúa-, invita a realizar un esfuerzo intelectual apasionante en el que los estudios literarios brillan en su máximo esplendor.

Laura Arroyo Martínez

Universidad Complutense de Madrid 